\title{
SIGNIFICANT MARKET POWER ACT EFFICIENCY
}

\author{
[Efektivita zákona o významné tržní síle] \\ Alena Filipová ${ }^{1}$, Veronika Mokrejšová ${ }^{2}$ Jiř́i Zeman $^{3}$ \\ ${ }^{I}$ Vysoká škola ekonomická v Praze, Fakulta mezinárodních vztahů, nám. W. Churchilla 4, 13067 Praha \\ Email:filipova@vse.cz \\ ${ }^{2}$ Vysoká škola ekonomická v Praze, Fakulta mezinárodních vztahů, nám. W. Churchilla 4, 13067 Praha \\ Email:veronika.mokrejsova@centrum.cz. \\ ${ }^{3}$ Vysoká škola ekonomická v Praze, Fakulta mezinárodnich vztahů, nám. W. Churchilla 4, 13067 Praha \\ Email:zeman@vse.cz
}

\begin{abstract}
Act No. 395/2009 Coll. on the Significant Market Power in the Sale of Agricultural and Food Products and Abuse thereof belongs to the specific legislation, through which the state regulates private law relationships between suppliers and buyers. The Act came into force in February 2010 after nearly a decade of its preparation and was accompanied by cut ones discussion of lawmakers, politicians, stakeholders and experts. During the period of its existence, the law is criticized both for its quality of legal and factual content. This study aims to assess the effectiveness of the law either in terms of its preventive and repressive action. The law was adopted with the expectation that it will help improve relations between suppliers and retail chains, empower suppliers and eliminate unfair practices. The team of authors has conducted an extensive primary research among suppliers. Evaluation of the results of this research and description of the findings of the Office for the Protection of Competition will then answer the question of whether the Act fulfilled the expectations and whether it is effective.
\end{abstract}

Keywords: significant market power, supplier, retailer, Office for the Protection of Competition.

JEL classification: L8

Doručeno redakci: 26.8.2013; Recenzováno: 5.5.2014; 11.5.2014; Schváleno k publikování: 11.2.2015

\section{Úvod}

V poslední době se zintenzivňuje zájem o Zákon č. 395/2009 Sb. o významné tržní síle při prodeji zemědělských a potravinářských produktů a jejím zneužití. Tento fakt se neodvíjí pouze od určité netrpělivosti subjektů zainteresovaných na řešení nedostatků zákona, ale rovněž se zákon opět stává politickou kartou ve hře o voliče.

Autoři této stati si nekladou za cíl posoudit kvalitu výše jmenovaného zákona ani $\mathrm{z}$ hlediska právního, ani z hlediska faktického obsahu a formulační erudice. Rovněž se pozornost nebude upírat na zkoumání odůvodněnosti existence zákona, kdy v diskuzích jsou používány občas argumenty populistické, tendenční či pseudoekonomické, bez hlubšího ukotvení v reálných datech. Stat' se zaměří na dopady zákona na dodavatele, resp. zda zákon naplnil obecná očekávání směrem k posílení vyjednávací pozice dodavatelů vůči retailingovým řetězcům a k odstranění praktik, které zákon vymezuje jako nežádoucí.

\section{Klíčové části zákona}

Zákon č. 395/2009 Sb. o významné tržní síle při prodeji zemědělských a potravinářských produktů a jejím zneužití vstoupil v platnost v únoru 2010, po téměř desetileté anabázi mezi jednotlivými zákonodárci. Zákon upravuje způsob posuzování a zamezení zneužívání tržní síly a vymezuje, kdo se rozumí dodavatelem (ten, kdo za účelem prodeje dodává zboží a služby odběrateli) a kdo odběratelem (ten, kdo odebírá zboží za účelem dalšího prodeje; tj. 
maloobchodník). Klíčovou částí zákona je vymezení samotné významné tržní síly. Tento pojem se zavádí pro konkrétní vztahy, kdy soutěžitel nemá dominantní postavení ve smyslu zákona č. 143/2001 Sb. o ochraně hospodářské soutěže. Významná tržní síla je „takové postavení odběratele vůči dodavateli, kdy se v důsledku situace na trhu stává dodavatel závislým na odběrateli ve vztahu $\mathrm{k}$ možnosti dodávat své zboží spotřebitelům a kdy si odběratel vi̊či dodavateli může vynutit jednostranně výhodné obchodní podmínky.“ Zákon č. 395 (2009, § 3) Významná tržní síla je tedy vymezena pouze jednostranně, kdy podle zákona jí může disponovat pouze odběratel, nikoliv ale dodavatel, a to bez ohledu na reálné postavení dodavatele na trhu ${ }^{1}$. Zákon stanoví, že by se měla tržní síla posuzovat s ohledem na trh, jeho strukturu a další parametry, nicméně jasnou hranicí je čistý obrat 5 mld. Kč². Odběratel s obratem nad 5 mld. Kč je považován za firmu mající významnou tržní sílu (pokud není prokázán opak).

Zneužití významné tržní síly je pak zákonem zakázáno. Co přesně se rozumí zneužitím významné tržní síly, je podrobně specifikováno v šesti prŕílohách zákona. Jde zejména o pravidla při fakturaci, kdy cílem je zabránit především retrospektivitě požadavků na slevy a podobně, dále o obchodní podmínky, kam patří podmínky nákupu, cenové podmínky, podmínky snižování cen a podmínky úhrady. Zde je např́iklad vymezena maximální platební lhůta za odebrané zboží na 30 dní od dodání zboží. Zákon č. 395 (2009)

Dále je zákonem zakázáno prodávat zboží pod nákupní cenou, tj. pod cenou, za jakou odběratel zboží nakoupil od dodavatele. Nicméně jsou zde vymezeny výjimky, kdy je tzv. podnákupní cena povolena. Velmi důležitá je př́loha zákona č. 5 , kde jsou poměrně podrobně definované jednotlivé praktiky, které zákon považuje vdodavatelsko - odběratelských vztazích za zakázané (ze strany odběratelů). Příklady zakázaných praktik jsou dále v textu, a to u výsledků primárního výzkumu.

\section{2 Šetření Úř̌adu na ochranu hospodářské soutěže}

Orgánem majícím dohled nad dodržováním zákona se stal Úřad pro ochranu hospodářské soutěže. Ve svých výročních zprávách se vždy k naplňování zákona vyjadřuje. První rok platnosti zákona (tj. rok 2010) prošetřoval úřad 41 podnět pro zahájení správního řízení z důvodu nedodržování zákona o významné tržní síle při prodeji zemědělských a potravinářských produktů a jejím zneužití. Došlé podněty upozorňovaly především na tzv. podnákupní ceny, a to zejména v sortimentu pečiva, cukru a mouky. Výsledně pak zahájil tři správní řízení. ÚOHS (2010) Dvě řízení se týkala společnosti Kaufland a jedno společnosti Ahold. Vzhledem k nutnosti rozsáhlého a podrobného zkoumání značného množství podkladů je nejen řízení záležitostí dlouhodobou, ale i samotná příprava řízení (resp. prošetřování podnětů) je náročná, takže je logické, že správní řízení nemohla být ukončena $\mathrm{v}$ daném roce. $\mathrm{V}$ roce 2011 se počet podnětů pro zahájení správního řízení zvýšil na 57. Byla zahájena tři správní řízení, a to se společnostmi Tesco, Lidl a Globus. Zároveň bylo zastaveno řízení proti společnosti Ahold, která předložila dostatečná nápravná opatření. Správní řízení proti společnosti Kaufland bylo zakončeno prvoinstančním rozhodnutím a udělením pokuty ve výši přesahující 13,6 mil. Kč. Kaufland proti tomuto rozhodnutí podal rozklad. ÚOHS (2011) V roce 2012 úřad obdržel celkem 23 podněty k zahájení správního řízení, nicméně po jejich prošetření žádné nové řízení zahájeno nebylo. Zároveň nebylo vydáno žádné rozhodnutí k probíhajícím správním řízením. Druhostupňové rozhodnutí zrušilo rozhodnutí týkající se společnosti Kaufland a vrátilo kauzu k novému projednání. ÚOHS (2012)

\footnotetext{
${ }^{1} \mathrm{Tj}$. za závislé na odběrateli jsou tak podle zákona považovány i firmy, jakými jsou např́íklad Coca Cola, Danone, Nestlé či Unilever.

${ }^{2}$ Tuto hranici ročního obratu přesahují všechny zahraniční řetězce provozující širokosortimentní prodejny.
} 
Shrnuto: za tři roky Úřad pro ochranu hospodářské soutěže prošetřil 121 podnět, zahájil správní ř́zení proti pěti společnostem $\mathrm{v}$ šesti záležitostech, $\mathrm{v}$ jednom př́padě šetření zastavil, v jednom př́padě vydal rozhodnutí, které bylo zrušeno a záležitost se vrací k novému projednání. V roce 2013 bylo podnětů nejméně a šetření doposud nebylo zahájeno žádné. ${ }^{3}$ Lze tedy říci na základě výše uvedených faktů - tj. ve světle toho, že nebylo vydáno rozhodnutí o nedodržování zákona, že úroveň a kvalita dodavatelsko-odběratelských vztahů mezi řetězci a jejich dodavateli se zlepšila? Je možné dovodit, že zákon z vyjednávání dotčených obchodních partnerů odstranil praktiky, které by bylo vnímat jako za nekalé či nátlakové? Splnil tedy zákon očekávání a došlo k posílení vyjednávací pozice dodavatelů?

\section{Dopady zákona na dodavatele}

Autoři dlouhodobě zkoumají dopady zákona o významné tržní síle při prodeji zemědělských a potravinářských produktů a jejím zneužití a po roce jeho platnosti uskutečnili sérii workshopů, kdy zjištovali názory obchodníků, potravinářů, prvovýrobců a jejich svazů. Zároveň se o své jednoleté zkušenosti podělili zástupci Ministerstva průmyslu a obchodu a Úřadu pro ochranu hospodářské soutěže. Následovalo dotazníkové šetření mezi členy Potravinářské komory. S odstupem jednoho a půl roku autoři na přelomu 2012/2013 s využitím předchozích zkušeností provedli další dotazníkové šetření, kdy bylo osloveno 500 dodavatelů potravin do maloobchodních řetězců. Byli osloveni zejména výrobci, ale část respondentů tvořili i distributoři potravin, resp. velkoobchodníci. Souběžně probíhal jiný výzkum mezi prvovýrobci (osloveno bylo 1400 respondentů), kteří byli požádáni, aby v prrípadě přímých dodávek maloobchodním řetězcům vyplnili také dotazník týkající se dopadů zákona o významné tržní síle při prodeji zemědělských a potravinářských produktů a jejím zneužití na jejich podnikání. Pro ochotu spolupracovat při dotazníkovém šetření bylo naprosto nezbytně nutné zachovat anonymitu respondenta ${ }^{4}$. Celkově byly zpracovány výsledky za 101 respondenta, přičemž $85^{5}$ respondentů patřilo mezi potravinářské výrobce či velkoobchodníky a distributory, $16^{6}$ respondentů byli prvovýrobci.

Otázky byly koncipované jako uzavřené, polouzavřené a otevřené, v některých byla použita škálovací technika. Pokud respondent nechtěl či neuměl odpovědět na otázku, mohl ji ponechat nezodpovězenou; výsledky tým pak vždy přepočítával na reálný počet odpovědí, nikoliv na celkový počet respondentů celého dotazování.

83 respondenti zodpověděli dotaz týkající se převažujícího původu vlastnického kapitálu; tři čtvrtiny $(75,9 \%)$ respondentů jsou firmy s převažujícím domácím (tj. českým) kapitálem. Téměř všichni respondenti (přesně 99) zodpověděli otázku týkající se velikosti; rozložení velikostní struktury ${ }^{7}$ ilustruje obrázek č. 1 .

\footnotetext{
${ }^{3}$ Toto shrnutí v žádném případě nezamýšlejí autoři jako kritiku práce Úřadu pro ochranu hospodářské soutěže! Informace, které musí úř̌ad k zaslaným podnětům prošetřit, jsou značně rozsáhlé. Je pochopitelné, že - vzhledem k určité kontroverznosti, která zákon doprovází - musí být rozhodnutí úřadu podloženo jasnými, přesnými a nevyvratitelnými fakty. $\mathrm{V}$ tom ale reálná kvalita zákona situaci úřadu neusnadňuje.

${ }^{4}$ Při prvním dotazníkovém šetření byl tým velmi překvapen obavami respondentů, a to přesto, že za zachování anonymity se zaručila Potravinářská komora, která vyplněné dotazníky shromažd’ovala. Návratnost dotazníků v prvním šetření tak byla pouze $\mathrm{v}$ řádu jednotek procent.

${ }^{5}$ Návratnost dotazníku tak činila $17 \%$, což autoři považují za úspěch vzhledem k citlivosti informací.

${ }^{6}$ Zde nemá smysl hodnotit návratnost dotazníků vzhledem $\mathrm{k}$ tomu, že výzkum se primárně věnoval jiné problematice a pouze malá část oslovených respondentů mohla patřit mezi př́mé dodavatele do řetězců.

${ }^{7}$ Pro členění dle velikosti bylo přijato standardní členění EU.
} 
Obrázek č. 1: Velikostní struktura respondentů v \% (n=99)

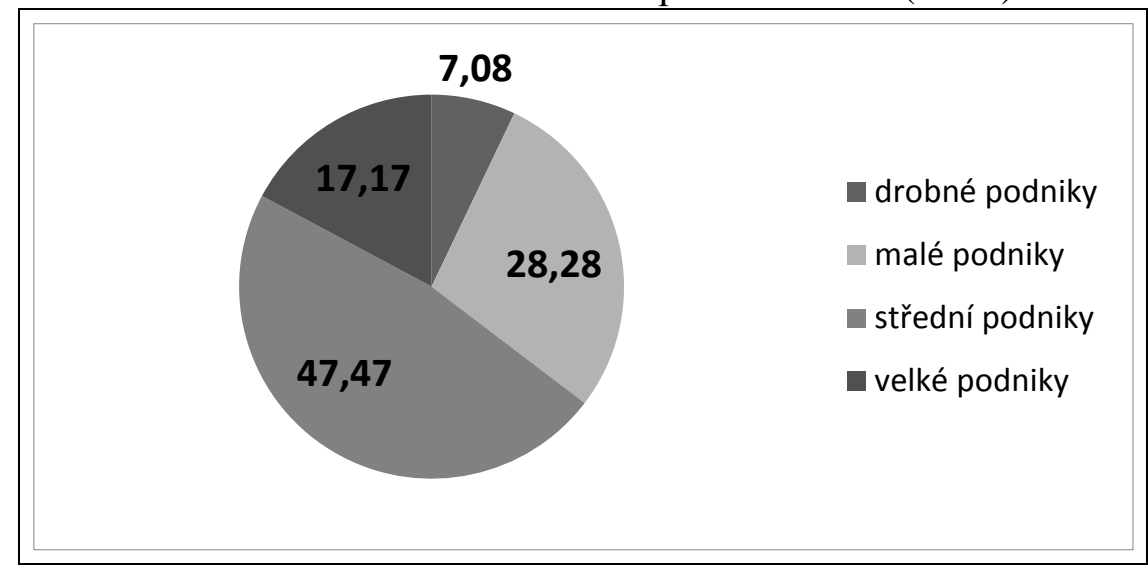

Zdroj: Vlastní výzkum.

Vzhledem $\mathrm{k}$ podílu českých firem a téměř $83 \%$ podílu malých a středních firem lze konstatovat, že struktura respondentů zhruba odpovídá subjektům, které zákon zamýšlel „chránit“.

Jedním z důsledků zákona by mohla (měla) být změna ve vztahu dodavatel - odběratel, at' už z hlediska jeho kvality či rovnocennosti postavení. Úvodní otázky šetření proto směřovaly $\mathrm{k}$ této skutečnosti. Odpovědi na otázku o změně vztahu s odběrateli po vstoupení zákona o významné tržní síle při prodeji zemědělských a potravinářských produktů a jejím zneužití v platnost jsou shrnuty $\mathrm{v}$ tabulce č. 1 .

Tabulka č. 1: Změna vztahu s odběrateli $(n=99)$

\begin{tabular}{|l|c|c|c|c|c|c|c|c|}
\hline \multirow{2}{*}{ Vztah se } & \multicolumn{5}{|c|}{ Počet podniků dle velikosti } & \multicolumn{3}{c|}{ Počet podniků dle původu kapitálu } \\
\cline { 2 - 9 } & drobný & malý & střední & velký & neuvedeno & domácí & zahraniční & neuvedeno \\
\hline $\begin{array}{l}\text { Výrazně } \\
\text { zlepšil }\end{array}$ & - & - & - & - & - & - & - & - \\
\hline Zlepšil & - & - & 2 & - & - & 2 & & - \\
\hline $\begin{array}{l}\text { Spíše } \\
\text { zlepšil }\end{array}$ & - & 3 & 7 & 2 & - & 9 & 2 & 1 \\
\hline Nezměnil & 4 & 22 & 36 & 15 & 2 & 48 & 17 & 14 \\
\hline $\begin{array}{l}\text { Spíše } \\
\text { zhoršil }\end{array}$ & 1 & 2 & 1 & - & - & 3 & 1 & - \\
\hline Zhoršil & - & 1 & - & - & - & 1 & - & - \\
\hline $\begin{array}{l}\text { Výrazně } \\
\text { se zhoršil }\end{array}$ & - & - & 1 & - & - & - & - & 1 \\
\hline
\end{tabular}

Zdroj: Vlastní výzkum. 
Obrázek č. 2: Změna kvality vztahu v \% $(\mathrm{n}=99)$

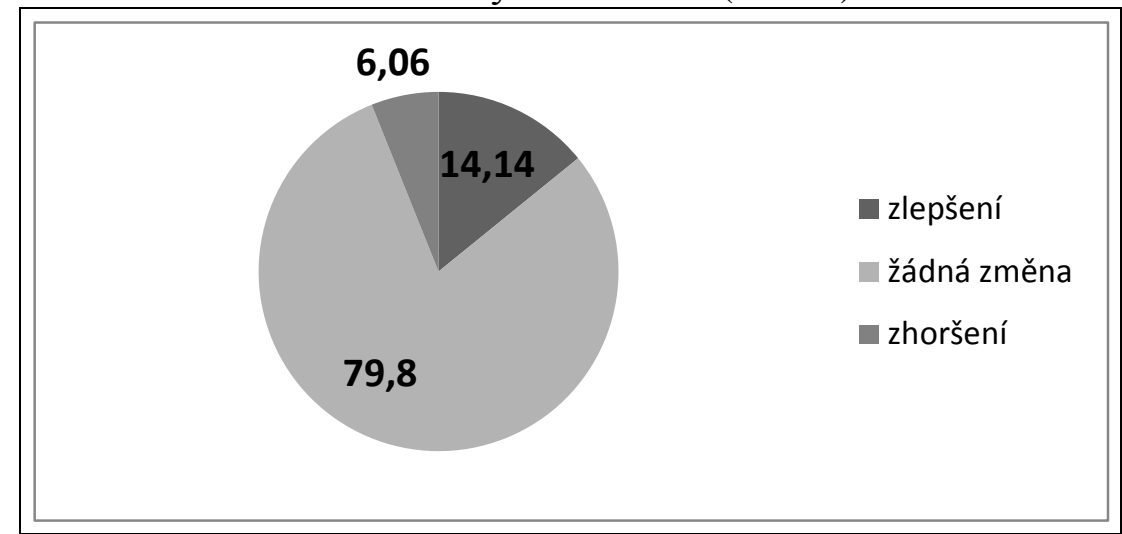

Zdroj: Vlastní výzkum.

Lze tedy konstatovat, že existence zákona o významné tržní síle při prodeji zemědělských a potravinářských produktů a jejím zneužití neměla na změnu vztahu téměř žádný vliv, viz obrázek č. 2. Hodnocení, zda jde pro dodavatele o pozitivní či negativní výsledek, záleží na původní kvalitě vztahu. Zajímavější výsledky tedy může poskytnout vyhodnocení odpovědí na otázku, zda se změnilo postavení dodavatelů vůči odběratelům z hlediska vyjednávací síly. Odpovědi na otázku o změně postavení při vyjednávání po vstoupení zákona o významné tržní síle při prodeji zemědělských a potravinářských produktů a jejím zneužití v platnost jsou uvedeny v tabulce č. 2 .

Tabulka č. 2: Změna postavení při vyjednávání $(\mathrm{n}=99)$

\begin{tabular}{|l|c|c|c|c|c|c|c|c|}
\hline \multirow{2}{*}{$\begin{array}{l}\text { Postavení } \\
\text { se }\end{array}$} & \multicolumn{5}{|c|}{ Počet podniků dle velikosti } & \multicolumn{3}{c|}{ Počet podniků dle původu kapitálu } \\
\cline { 2 - 9 } & drobný & malý & střední & velký & neuvedeno & domácí & zahraniční & neuvedeno \\
\hline zlepšilo & - & - & - & - & - & - & - & - \\
\hline Zlepšilo & - & - & 1 & 1 & - & 2 & - & - \\
\hline $\begin{array}{l}\text { Spíše } \\
\text { zlepšilo }\end{array}$ & - & 1 & 5 & 1 & - & 3 & 2 & 2 \\
\hline Nezměnilo & 4 & 24 & 38 & 15 & 1 & 52 & 17 & 13 \\
\hline $\begin{array}{l}\text { Spíše } \\
\text { zhoršilo }\end{array}$ & 1 & 1 & 2 & - & 1 & 4 & 1 & - \\
\hline Zhoršilo & - & 2 & - & - & - & 2 & - & - \\
\hline $\begin{array}{l}\text { Výrazně } \\
\text { se zhoršilo }\end{array}$ & - & - & 1 & - & - & - & - & 1 \\
\hline
\end{tabular}

Zdroj: Vlastní výzkum.

Obrázek č. 3: Změna postavení dodavatelů při vyjednávání v \% $(\mathrm{n}=99)$

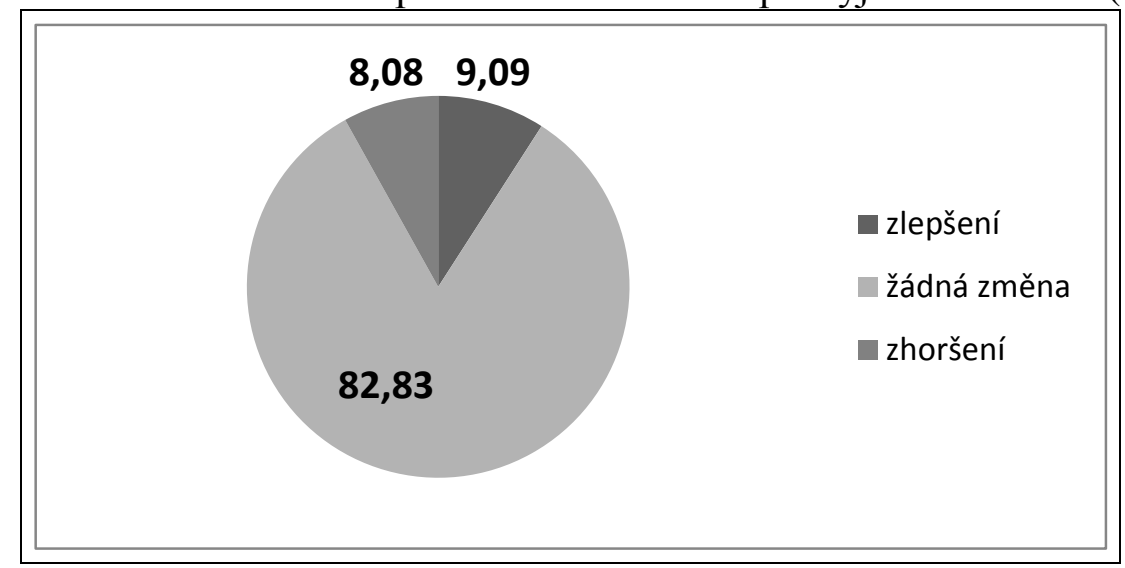

Zdroj: Vlastní výzkum. 
Tento výsledek (viz obrázek č. 3) lze svým způsobem pro zákonodárce a iniciátory zákona považovat za alarmující. Pokud zákon nenaplňuje základní očekávání, pak je možné jej považovat za zbytečný. Signifikantní rovněž je, že zhoršení pocit’ují malé a střední podniky, kterým zákon zamýšlel dopomoci k rovnocennějšímu partnerství.

Zákon rovněž vymezuje určité praktiky, které v obchodním vztahu dodavatel - odběratel považuje za nežádoucí. Dotazníkové šetření zkoumalo, jak často se uvedené praktiky vyskytovaly před prrijetím zákona o významné tržní síle při prodeji zemědělských a potravinářských produktů a jejím zneužití a zda i po vstoupení zákona v platnost se respondenti s touto praktikou setkali. Častost výskytu shrnuje tabulka č. 3.

Tabulka č. 3: Častost výskytu praktik v obchodním vztahu v \% $(\mathrm{n}=99)$

\begin{tabular}{|c|c|c|c|c|c|}
\hline \multirow[b]{2}{*}{ Praktika } & \multicolumn{4}{|c|}{ Častost výskytu praktiky před zavedením zákona } & \multirow{2}{*}{$\begin{array}{c}\text { Podíl } \\
\text { respondentů, } \\
\text { kteří se s danou } \\
\text { praktikou } \\
\text { setkali i po } \\
\text { zavedení } \\
\text { zákona }\end{array}$} \\
\hline & velmi často & často & zřídka & nikdy & \\
\hline $\begin{array}{l}\text { Smluvně dojednaná delší než } \\
\text { 30-ti denní lhůta splatnosti } \\
\text { faktur }\end{array}$ & 30 & 36 & 29 & 5 & 43 \\
\hline Vratky & 7 & 26 & 58 & 9 & 25 \\
\hline $\begin{array}{l}\text { Prodej zboží pod nákupní } \\
\text { cenou }\end{array}$ & 20 & 25 & 43 & 12 & 34 \\
\hline $\begin{array}{l}\text { Automatický odečet ztrát, } \\
\text { pokut a sankcí za pozdní } \\
\text { dodávku či nevyhovující stav } \\
\text { zboží z faktury }\end{array}$ & 21 & 39 & 28 & 12 & 42 \\
\hline $\begin{array}{l}\text { Započtení pohledávky } \\
\text { dodavatele vǔči odběrateli bez } \\
\text { písemného souhlasu } \\
\text { dodavatele }\end{array}$ & 24 & 38 & 22 & 16 & 47 \\
\hline $\begin{array}{l}\text { Uplatňování retroaktivních } \\
\text { slev }\end{array}$ & 16 & 39 & 29 & 16 & 36 \\
\hline $\begin{array}{l}\text { Požadování auditu výroby na } \\
\text { náklady dodavatele }\end{array}$ & 21 & 29 & 27 & 23 & 40 \\
\hline $\begin{array}{l}\text { Náhlé přerušení obchodního } \\
\text { vztahu }\end{array}$ & 6 & 19 & 51 & 24 & 26 \\
\hline $\begin{array}{l}\text { Přenesení sankcí na } \\
\text { dodavatele bez prokázaného } \\
\text { zavinění }\end{array}$ & 3 & 19 & 54 & 24 & 31 \\
\hline $\begin{array}{l}\text { Odmítnutí uvést výrobce na } \\
\text { produkt privátní značky }\end{array}$ & 9 & 18 & 36 & 37 & 24 \\
\hline
\end{tabular}

Zdroj: Vlastní výzkum.

Nutno konstatovat, že před přijetím zákona o významné tržní síle při prodeji zemědělských a potravinářských produktů a jejím zneužití se s praktikami, které zákon v obchodním vztahu zakazuje, setkala většina firem, ačkoliv míra výskytu jednotlivých praktik byla rozdílná. Nejvíce uplatňovanou praktikou byla dlouhá doba splatnosti faktur, a to i u rychloobrátkového zboží. Na druhou stranu z výzkumu i workshopů vyplynulo, že zrovna s touto praktikou se uměli dodavatelé dobře vypořádat, protože - i když šlo o dlouhou splatnost faktury - tak platební morálka řetězců byla dobrá a v dohodnutých termínech platby byly jisté. Nejmenší četnost praktiky odmítnutí uvést výrobce na produkt privátní značky může souviset $\mathrm{s}$ tím, 
že ne každý dodavatel se podílí na výrobě privátních značek; z logiky věci se pak s touto praktikou nesetkává. Překvapivý je ale vysoký podíl respondentů, kteří se s uvedenými praktikami setkali i po vstoupení zákona o významné tržní síle při prodeji zemědělských a potravinářských produkti̊ a jejím zneužití v platnost. Pokud by byl zákon efektivní, pak bud' by se dané praktiky nevyskytovaly (to $\mathrm{v}$ ideálním př́padě $\mathrm{z}$ hlediska zákona), nebo by byl Úřad pro ochranu hospodářské soutěže zavalen podněty $\mathrm{k}$ šetření a uděloval by pokuty za nedodržení zákona. Praxe ale nepotvrzuje ani jednu z variant.

Podobná situace je i u poplatků, které odběratelé vybírají a zákon je chápe jako neopodstatněné či nepřiměřené. $V$ písemných komentářích dodavatelé uvedli řadu příkladů ilustrujících skutečnost, že se odběratelé dokázali přizpůsobit tak, že liteře zákona je vyhověno, ale v realitě praktika či poplatek zůstaly zachovány. Prof. Bejček toto velice názorně a trefně komentoval slovy „.... strukturální rozdíl v asymetrické vyjednávací pozici a vyjednávací síle stran se tím (myšleno zákonnou restrikcí - pozn. autorů) přece nesmaže, jen se přesune, resp. transformuje jinam a projeví se jinde ve smlouvě, resp. i mimosmluvně zkrátka tam, kde je to př́pustné. Tržní a vyjednávací převaha se nepřestane prosazovat; nanejvýš změní formu a zdokonalí „mimikry“.“ Bejček (2012, s. 21) Např́klad dvě nejviditelněji „odstraněné“ praktiky z obchodního vztahu v realitě znamenaly pro mnoho dodavatelů tyto změny: zkrácení doby splatnosti faktury na maximálně 30 dní s sebou přineslo tlak na snížení nákupní ceny $\mathrm{z}$ důvodu jiné časové hodnoty peněz ${ }^{8}$; zákaz vratek znamená pro dodavatele častější závoz zboží a pro spotřebitele absenci některých druhů zboží (např. pečiva) před zavírací dobou prodejny. Některé poplatky změnily své názvy, př́padně použití určité praktiky je zaneseno do smlouvy, kterou dodavatel s odběratelem podepisuje.

\section{Závěr}

Je možné tedy říci, že v realitě očekávání, která byla vkládána zákonu o významné tržní síle při prodeji zemědělských a potravinářských produktů a jejím zneužití do vínku, naplněna nebyla. Do vztahu mezi dodavatelem a odběratelem, kterých se zákon týká, nebylo vneseno př́lišs změn, a lze tedy o efektivním fungování daného zákona pochybovat. Další osud zákona je poměrně nejistý. Již před vstupem v platnost vyjadřovaly nespokojenost se zákonem všechny zainteresované strany i další odborná veřejnost, ačkoliv argumenty a motivy nebyly vždy shodné. Již v roce 2011 meziresortní komise doporučila zákon zrušit a některá ustanovení přenést do jiných zákonů. Symptomatické je však, že ani do současné doby nebyla novelizace zákona o významné tržní síle uskutečněna a zákon platí ve své původní podobě.

\section{Poděkování}

Tento článek vznikl v rámci institucionální podpory Fakulty mezinárodních vztahů Vysoké školy ekonomické v Praze.

\section{Literatura}

[1] BEJČEK, J., 2012. Úprava tzv. významné tržní síly: přirozený krok k ochraně spotřebitele a slabšího, nebo „papírový tygr“ (a škůdce soutěže a spotřebitele)? Bulletin advokacie [online]. 7-8, 15-25 [vid. 30. června 2013]. ISSN 1210-6348. Dostupné z: http://www.bulletin-advokacie.cz/assets/zdroje/casopis/2012/ba_7_8_2012_web.pdf

[2] Usnesení č. 266 ze dne 17. dubna 2013 k poslaneckému návrhu zákona, kterým se zrušuje zákon č. 395/2009 Sb., o významné tržní síle při prodeji zemědělských a potravinářských produktů a jejím zneužití (sněmovní tisk č. 948). Vláda České

\footnotetext{
${ }^{8} \mathrm{Z}$ tohoto důvodu by i někteří dodavatelé přivítali návrat $\mathrm{k}$ dřívějšś úpravě, kdy bylo možné si dobu splatnosti smluvně dojednat.
} 
republiky [online]. [vid. 30. června 2013]. Dostupné z: http://kormoran.vlada.cz/ usneseni/usneseni_webtest.nsf/0/0F095DA9BD016163C1257B59002259CB/\$FILE/266 \%20uv130417.0266.pdf

[3] Zákon č. 143/2001 Sb., o ochraně hospodářské soutěže a o změně některých zákonů (zákon o ochraně hospodářské soutěže). Úřad pro ochranu hospodářské soutěže [online]. [vid. 30. června 2013]. Dostupné z:http://www.uohs.cz/download/Legislativa/HS/ CR/uplne-zneni-2012-360.pdf

[4] Zákon č. 395/2009 Sb., o významné tržní síle př̌i prodeji zemědělských a potravinářských produktů a jejím zneužití. Úřad pro ochranu hospodářské soutěže [online]. [vid. 30. června 2013]. Dostupné $\mathrm{z}$ : http://www.uohs.cz/download/Legislativa/HS/ CR/2009_395.pdf 